\title{
The Impact of Using Drama in Education on Life Skills and Reflective Thinking
}

\author{
https://doi.org/10.3991/ijet.v14i09.7978 \\ Hani Yousef Jarrah \\ Al-Ain University, Abu Dhabi, UAE \\ hani.jarral@aau.ac.ae
}

\begin{abstract}
The study aimed to identify the impact of using drama in education on life skills and reflective thinking. The experimental method was used, and the study sample consisted of (100) students from the 10th grade at the Emirates National School in Abu Dhabi. The results showed that drama in education has an impact on life skills as it develops students' reading and numeracy skills, enables them to identify the strengths and weaknesses of their personality, and to connect study and application in real life. Employing drama in education increased students' skills in reflective thinking regarding reinforced the different concepts logically analysis and a distinction between the advantages and disadvantages of different topics. The researcher recommended that the teacher should focus on the development of students' abilities to deduce solutions to the problems posed by the available information on the nature of the problem and traits.
\end{abstract}

Keywords—Drama, life skills, reflective thinking

\section{Introduction}

The attention and care of education are not new. Since ancient times, this subject has prominent importance. The education has gone through many stages and has evolved. The methods of receiving education are more efficient and focused on attracting the student to stimulate his mind and bring out the best of his intelligence and creativity. With this great progress sweeping the world in various fields, there is abundant wealth of information available which adds pressure on the students. It leads to the need to develop education and the use of different teaching methods more effective and powerful for each student. Commensurate with age and psychological development, such methods would expand their educational potential, and then invest it in maximizing their performance; thereby, increasing their chances of success and helping them to integrate into the learning environment and diminish their vulnerabilities.

It has become clear that many teachers are seriously considering using new means of education such as drama as a means of explaining the teaching of different subjects such as science, mathematics, and language. The idea came from the educational programs offered by television and the scientific and social information they provide 
through drama. The student is either read or narrated as far as this is when the class is a field for presenting the vocabulary and concepts in a dramatic and exciting drama [1].

Emphasized that the educational process must be an integral responsibility of the teacher and the learner. It has been shown that drama is a technical model that helps to apply this method and works to develop visions and understanding through research, understanding and planning. It is also attractive, as events can be described smoothly to facilitate understanding of students, and is effective in that they develop or move the imagination and contemplative thinking of the recipient, which enables him to increase his life skills [2].

The importance of drama in education is that it helps to develop the learner's thinking and get rid of the stodgy atmosphere of education; characterized by repetition and stagnation. Also, it helps to develop his personality through integration and work and cooperation with the group. Therefore, it is a successful educational method and a medium of learning. Some methods are used to convey an educational idea to the student. The state of stalemate is broken, and the learner's understanding of the ideas in his or her natural life deepens. This leads to the development of creative thinking and develops mental, psychological, cultural, and social levels [3]. It can be said that contemplative thinking is the look and thinking of the individual in depth to all what is happening in the environment. Consider the idea from several aspects, including the presentation of elements, and know the reasons that led to the results by linking ideas to each other. It establishes a good understanding of things, and also develops the ability to analyze its performance. Also, to identify the ideas and beliefs behind them, and their consequences, leading to new knowledge and decisions contributing to the development of itself, and reflective thinking makes the student always planning and reflecting on all the information presented to him, while this has the effect of learning in the mind of the learner, and therefore Enhances life skills [4].

\section{Problem of the Study}

The methods used in teaching are often based on traditional methods of indoctrination. However, this method does not attract the attention of students enough, and this reflects negatively on the development of life skills and reflective thinking, so it was necessary to use an educational method that improves their level. The students were naturally interested in interactive animation activities. It was necessary to use a method that fostered their love of learning. The choice was based on the educational method that interestingly presents the subjects and makes the students the focus of the teaching process [5]. Found that there are many obstacles to the application of different methods of education, such as the dependence of most teachers on the education system. Moreover, there is lack of qualified teachers to use thinking-based teaching strategies, and the adoption of curriculum and educational management modules on tests that measure conservation and focus only away from reflection, reflection, and reasoning. To improve the educational process, the educational method of drama has been adopted as a kind of innovation in educating the students and to facilitate stu- 
dent's understanding, which increases their love for education and makes them active members of society.

\subsection{Question of the study}

This study seeks to answer the following questions:

- What is the effect of the use of drama in education on the life skills of the tenthgrade students?

- What is the effect of the use of drama in education on the contemplative thinking of the tenth-grade students?

\subsection{The purpose of the study}

This study aims to:

- The impact of the use of drama in education on the life skills of students in the tenth-grade.

- To recognize the impact of the use of drama in education on the reflective thinking of the tenth-grade students.

\subsection{The importance of studying}

This study seeks to highlight the importance of diversifying the methods and methods of education by using the dramatic method in developing life skills and reflective thinking among students and not relying on the rigid scientific content found in educational curricula. The tendency to use drama in education stimulates students and develops their mental abilities, which increases the knowledge of himself and his abilities and knowledge of the skills and talents, and these skills are important to enable the individual to communicate with others and interact with them, so that it facilitates the achievement of its objectives successfully, in addition to the development of the ability to reflective thinking. The analysis of things makes logical sense of things in a way that makes it easy for the student to make many important decisions in his life, so it is important to train teachers on this methodology, which adds a lot of fun and excitement to the student more interested in the content of books. The researcher also hopes that this study will help encourage officials in the Ministry of Education to organize or modify the educational curricula to give students the opportunity to develop their abilities. Intellectual and drama education becomes the approach taken in schools because of its positive impact on the educational process and development, and that teachers are encouraged and adequately trained to help them diversify their teaching methods so that suit all types of students [6]. 


\section{$2.4 \quad$ Terminology}

Drama: Drama is an artistic form of literature that has been linked regarding language to story and story, and has differed from them in portraying the conflict, embodying the event, and intensifying the knot. The drama may take the form of poetry, weight, and rhyme, or free of these two forms and take the form of prose [7].

Life skills: A group of skills that students learn systematically through the activities and scientific applications related to the environment in which they live, which enable them to deal with the requirements of daily life successfully and aims to build character in a way that enables them to take responsibility [8].

Reflective thinking: It is the ability to see, to understand the relationships, to use the data to identify and strengthen the learner's point of view, to review the alternatives, and to take appropriate action on the educational situation [9].

\subsection{The limits of the study}

Sample limits: The present study was applied to the tenth-grade students.

Place limits: The current study was implemented at Emirates National School in Abu Dhabi.

Time Limits: The current study was implemented during 2017.

\section{Theoretical Framework and Previous Studies}

The drama focuses on the scientific facts and concepts. Also, watching the play helps to understand the events and remember them for a longer period, which significantly affects the learner and develops his methods of problem-solving in a serious scientific way. It develops the skills of reading and corrects pronunciation. It also provides an artistic and aesthetic taste resulting in the development of practical imagination and creativity skills by imagining events. It helps in predicting what happened, free fun and joy to the hearts of the learners, and to provide an atmosphere of friendship and friendliness between the teacher and the learner, which fosters positive trends [10].

Also see that the use of such activities is important and significant in developing the process of learning and understanding among students. The student interacted with the rest of the students in the classroom under the supervision and direction of the teacher, to play a specific role to gain him and the viewers a sense that they all grow towards the desired direction [11].

Explain that the multiplicity of knowledge at the end of the twentieth century led to a major development in the scientific fields of earth sciences, environment, biology, and prehistory sciences. This multiplicity led teachers to search ways to increase the individual's ability to learn by him and not to just increase his knowledge. Through inductive reasoning, in traditional education, and teaching by example the art of searching for strategies the teacher offers the learner self-learning skills, something necessary and important. This is done by the teacher analyzing the lessons and ex- 
pressing the content within different contexts, while using the drama played by students to promote understanding of the curriculum [12].

Stressed that the use of drama in education is an effective means of acquiring proper manners and behaviors [13].

Life skills have a great impact on students' lives. They make them able to cope with different life situations, and develop the ability to overcome and deal with life problems wisely, precisely like when the individual has the skills of language communication, and this gives him the ability to express his ideas clearly.

The life skills of students also develop the use of thinking. This is one of the successful methods that motivate the individual to achieve and build his personality in a unique way. The more the individual understands the things around him, the more he has the ability to acquire many skills. The basic idea is teaching the human how to think and infer by themselves, as opposed to receiving ideas from others, so the teacher must use multiple methods to enrich and stimulate thinking in students. For example, teacher can use the method of asking relevant questions, or the method of dramatic expression of attitudes relating to the course material. these enhance students' thinking revealing the real knowledge underlying the educational situation, which in turn gives students an opportunity to clarify and reflect what they have learned, and thus create a reasonable answer and build logically correct generalizations [14]

The practice of contemplative thinking makes the individual a distinct personality compos of many characteristics and qualities, such as listening to others and understanding, and reducing the rush impulsiveness and recklessness, and allowing flexibility in thinking and scrutiny and control, and understanding the behavior of others emotional and emotional reactions, and managing to act effectively in unexpected situations while reacting to what is happening around, and considering it, and practicing reflective thinking on the development of the skills of literary students, which strengthens them with multiple skills that make them more creative [15].

Believe that reflection is of great importance as it teaches students to reach logical and correct results in the situations they face inside and outside school, as it increases their efficiency, and develops their ability to reach the right results. Students learn to find the way to become contributors to the development of their future, as well as to develop their emotional skills, while teacher contribute in helping students understand the content of the study, which leads to raising their level of achievement. Therefore, it is necessary to ensure that the neglect of any aspect of education and its multiple methods can lead to a defect in the educational process [16].

Investigate the significance of creative drama studies in math education. Their study evaluated 17 articles in the context of data collection and analysis techniques to investigate the relationship. Their findings asserted that there is a lack of literature in studying the relationship between creative drama studies and its impact on the mathematics education. However, the available studies reflect a positive impact of using creative drama techniques in the mathematics education. These impacts are highlighted by the increased creativity and student achievement. The researchers carried out a meta-analysis and explored the attitudes and perceptions of primary school students towards mathematics. Retention, thinking levels, perceptions, self-concept, mathematical abilities \& achievement, and creativity were the key outcome variables. Based on 
the findings, the researchers assert that drama-lessons are helpful in establishing a positive attitude towards geometry class in primary students. It helps them in creating self-concepts as well as opportunity to improvise. Improvisation is a creative skill that cannot be inculcated through passive teaching techniques. They also suggested that there is a need for further qualitative studies in the field [17] \& [18].

Drama teaching methods are part of Current education approaches; they are basically the methodologies that show students approaches to secure knowledge instead of retaining it. This accommodates the advancement of different learning models and teaching techniques that empower the structuration and revelation of knowledge by the students themselves [19]. Based on the philosophy, conducted a case study to evaluate the impact of creative drama methodology as a constructivist approach to complement science subjects. The researchers used qualitative data tools to identify and understand the teachers and students perspective regarding the application of creative drama approach or method in the science education. Their findings reveal that the method assists in social development of students and equip them with communication skills. The study was conducted among 6th-grade students and science teachers through means of focus groups and observations. The findings reveal that among the benefits of creative drama as far as instructing Science and Technology; aggregate activities performed amid the drama workshops guarantee social improvement, information imparted in science and technology books can be educated in a less demanding and more agreeable and delighted way as a part of the drama technique. Students showed that they could take in more effortlessly and with more happiness. Learning through drama is a form of contemporary education, which enables learners to become active and inquisitive. They participate to be able to learn which contributes in their development [20].

Studying the impact of drama as an educational intervention. Their paper asserts that drama as an educational tool has been broadly actualized in education and in clinical settings. The effectiveness of utilizing theater as a way to advance change by exploiting its forceful emotional part has been ascribed to two fundamental capacities: a cathartic capacity as well as performative. The researchers, through their findings, suggest that the drama technique permits the students to relate to the characters and may even change their perspective [21]. Moreover, students can utilize drama systems to depict regular day to day existence situations, endeavoring to consider social issues from alternate points of view. Notwithstanding the far reaching utilization of theater workshops in educational and clinical settings, an issue that requires examination and research is the evaluation of their effectiveness. Their paper suggests that several reasons contribute to making the workshops' effectiveness hard to survey. An observation of strategies for evaluating the effectiveness of drama mediation is exhibited in this paper, and a proposition for assist investigation is given.

Likewise, examined drama is a pedagogical approach in instructing investment management course to the students. Their sample included group of students from Sydney and Hong Kong. They studied the perceived learning patterns. The two different groups helped formulate a cross-cultural comparison to determine the effectiveness of educational drama as a method. However, the findings suggested that despite 
the cultural differences educational drama can be used effectively in teaching investment management [22].

Explore the impact of theater-in-education on imagination and language. The researcher carried out a quantitative assessment of drama education and its effect on the acquisition of skills such as perspective-taking, and development of language and imagination. The findings of the study reveal that theater or drama is an engaging and entertaining way to educate pre-school students [23].

\section{Previous Studies}

Through the researcher's knowledge of literature and previous studies on the subject was able to reach a number of studies related to it. Some studies have revealed the impact of drama on life skills and reflective thinking among students showed the impact of using drama on developing life skills in Arabic [24]. The list of life skills suitable for female students was found including students' understanding of social concepts, their understanding, and their awareness of what is happening around them. Found that there was a significant difference in the oral communication skills between the two groups [25]. For comparison, one group was introduced to educational drama and the other group was instructed in the conventional way. Worked on creativity (authenticity, resistance to premature closures, preparation, fluency, and abstraction of titles) [26]. They explained that drama-based education makes education easier to understand and better overall by providing the opportunity to put engineering contexts, communication and study into a collaborative learning environment. Moreover, it motivates attitudes by drawing students' attention to an exciting, stimulating, and interesting learning environment. Concerning theatrical drama, showed that there are statistically significant differences in the percentages and frequency amongst the three main axes, linguistic health, audio-visual, clarity, composition, and performed analysis between pre-drama and theater, and after drama was used [27].

Identified the effect of the use of drama activities as an educational strategy on the achievement of sixth grade students, and found that there were statistically significant differences in the post-test between the two groups due to the teaching method (traditional and dramatic) [28]. Investigated the influence in the use of drama in teaching English and students' ability to develop their creative thinking, and showed that the scores of the group studied using the dramatic method had higher ones than those of the group studied in the traditional way [29].

The methodology of the study: To achieve the objectives of the study, the researcher used the semi-experimental approach for the purpose of the current study, and since the researcher cannot adjust all the variables, as the selection of samples in the study was not random, the methodology used is a semi-experimental approach that reflects the study of differences between two samples [30].

Population of the study: The study population is composed of a group of 10the grade students at the Emirates National School in Abu Dhabi for the academic year (2016/2017). The number of students in the tenth-grade is 132 male students only. 
Sample of the Study: The study sample consisted of (100) students who were deliberately selected from the 10th grade students at the Emirates National School in Abu Dhabi [31].

The study Instrument: The researcher constructed two measurements (Pre and post) to collect information and used for comparison purposes the data from the sample of the study in order to achieve the aims of the study that seeks to understand the effect of using drama on reflective thinking and life skills [32].

\subsection{The reflective thinking measurement}

The first part includes the personal information of the sample of the study, while the second part includes (20) paragraphs measuring the level of contemplative thinking among the students of the tenth grade.

Validity of the reflective thinking measurement: The researcher verifies the indicators of the validity of the reflective thinking by presenting it to a number of arbitrators with experience and competence in the curriculum, teaching, measurement and evaluation, in order to judge the degree of integrity of the language, and the extent of belonging to the scale, in addition to any action necessary to delete, edit, or add.

For the purpose of extracting the structural validity indicators for all the scales, it was applied to a survey sample of (15) individuals from the study community and from outside the original sample, and to calculate correlation coefficients between each paragraph and the tool as a whole [33].

Table 1. Correlation Coefficients

\begin{tabular}{|c|c|c|c|}
\hline Number & $\begin{array}{c}\text { Correlation co-efficient with total } \\
\text { degree }\end{array}$ & Number & $\begin{array}{c}\text { Correlation co-efficient with total } \\
\text { degree }\end{array}$ \\
\hline 1 & $.58^{* *}$ & 11 & $.76^{* *}$ \\
\hline 2 & $.59^{* *}$ & 12 & $.69^{* *}$ \\
\hline 3 & $.60^{* *}$ & 13 & $.64^{* *}$ \\
\hline 4 & $.67^{* *}$ & 14 & $.74^{* *}$ \\
\hline 5 & $.75^{* *}$ & 15 & $.57^{* *}$ \\
\hline 6 & $.71^{* *}$ & 16 & $.63^{* *}$ \\
\hline 7 & $.80^{* *}$ & 17 & $.73^{* *}$ \\
\hline 8 & $.72^{* *}$ & 18 & $.61^{* *}$ \\
\hline 9 & $.79^{* *}$ & 19 & $1.5^{* *}$ \\
\hline 10 & $.67^{* *}$ & 20 & $.70^{* *}$ \\
\hline
\end{tabular}

*Correlation coefficients are significant at $(\alpha \leq 0.05)$

$* *$ Correlation coefficients are significant at $(\alpha \leq 0.01)$.

Reliability of the reflective thinking measurement: The reliability of the life skills scale was verified by applying it twice by two weeks to a sample of 15 individuals from the study population and outside the original sample. The Pearson correlation coefficient was calculated between the two applications to extract the reliability. Also, the stability equation of the tool (Cronbach's Alpha) was applied. The value of Cronbach's Alpha coefficient was (0.87) and the (R-test) was (0.83), these values being high enough and deemed acceptable for the purpose of the present study [34]. 


\subsection{The life skills scale}

The life skills measure is divided into two parts. The first part includes the personal information of the study sample members. The second part includes (20) items that measure the level of life skills of the tenth grade students [35].

The life skills scale validity: The researcher verifies the indicators of the veracity of the life skills standard by presenting it to a number of experienced and competent arbitrators, in order to judge the accuracy of the language, the extent to which the paragraph belongs to the scale, as well as any necessary action to delete, modify, or add [36].

For the purpose of extracting the structural validity indicators for all the scales, it was applied to a survey sample of (15) individuals from the study community and from outside the original sample, and to calculate correlation coefficients between each paragraph and the tool as a whole.

Table 2. Correlation Coefficients with Total Degree

\begin{tabular}{|c|c|c|c|}
\hline Number & $\begin{array}{c}\text { Correlation co-efficient } \\
\text { with total degree }\end{array}$ & Number & $\begin{array}{c}\text { Correlation co-efficient } \\
\text { with total degree }\end{array}$ \\
\hline 1 & $.65^{* *}$ & 11 & $.57^{* *}$ \\
\hline 2 & $.68^{* *}$ & 12 & $.55^{* *}$ \\
\hline 3 & $.56^{* *}$ & 13 & $.57^{* *}$ \\
\hline 4 & $.65^{* *}$ & 14 & $.61^{* *}$ \\
\hline 5 & $.51^{* *}$ & 15 & $.63^{* *}$ \\
\hline 6 & $.53^{* *}$ & 16 & $.65^{* *}$ \\
\hline 7 & $.69^{* *}$ & 17 & $* * 9.7$ \\
\hline 8 & $.59^{* *}$ & 18 & $.65^{* *}$ \\
\hline 9 & $.48^{* *}$ & 19 & $.71^{* *}$ \\
\hline 10 & $.64^{* *}$ & 20 & $.62^{* *}$ \\
\hline
\end{tabular}

*Correlation coefficients are significant at $(\alpha \leq 0.05)$.

**Correlation coefficients are significant at $(\alpha \leq 0.01)$.

The life skills scale reliability: The measure of life skills was confirmed by applying two times by two weeks to a survey sample of 15 individuals from the study population and outside the original sample. The Pearson correlation coefficient was calculated between the two applications to extract the test-retest; the stability equation of the tool (Cronbach's Alpha) was also applied. The value of Cronbach's Alpha coefficients was 0.89 and the Pearson's bivariate correlation coefficient (R-test) reliability of the scale (0.86) was high and acceptable for the applied of this study.

Instruments scales: The contemplative scale of reflection with its final form of (20), and the life skills measure (20). The researcher used the five Likert scale in order to measure the opinions of the sample of the study sample, and was strongly approved (5), (4), neutral (3) ), Disagree (2), strongly disagree (1), by making a reference $(\times)$ to the answer reflecting their degree of approval, and the following classification is based on the calculation means: anything less than 2.33 will be categorized as low, from 2.34 to 3.66 as medium, and from 3.67 to 5 as high [37]. 
Design of the study: The researcher used the semi-experimental method in detecting the effect of the use of drama on reflective thinking and life skills. The researcher depends on experimental one group; the method of drama was implemented.

\section{Study variables}

- Independent variable

Time of measurement, has two levels: - pre and post

- The dependent variable

- Life skills

- Reflective thinking

Statistical processing: To extract the results, the following statistical treatments were used using the Statistical Package for Social Sciences (SPSS) program:

- The mean and the standard deviations of the performance of the 10th grade students on the life skills and the reflective thinking.

- Paired sample t-test (otherwise called dependent sample t-test) was applied to investigate the effect of using drama in education on life skills and reflective thinking.

\section{$5 \quad$ Results of the Study}

This section includes the results of the study aimed at the effect of the use of drama in education on life skills and reflective thinking. The results will be presented based on the study questions.

\section{Descriptive Statistics}

Table (3) shows that the mean for the "life skills" area ranged from (3.53-4.02), the highest of which is paragraph (17), which states "possess reading and numeracy skills" with an average of 4.02 and high, then (9) which states: "Link between study and application in real life" with an average of (3.95) and a high degree, While the lowest of paragraph (4), which states "distinguish between truth and opinion" with an average of (3.53) and a middle degree, and the arithmetic mean of the area "skilled Life "as a whole (3.80) and high degree. This is due to the fact that drama is an effective method that utilizes student activity and helps in learning through the representation of the texts in a dramatic form. This leads to increasing awareness among students and enhancing their understanding of the information so that they can develop their ability to express and think critically and enhance their self-confidence. Their ability to read and calculate, and that drama helps students to identify their weaknesses, which helps them to develop and work to avoid that weakness, so that the student to show himself in a confident personal image. The results of this study were in line 
with the results of the study, which showed the effect of the use of drama on the development of life skills in the Arabic language, and a list of life skills suitable for students to develop their skills.

Table 3. Descriptive Statistics of Life Skills

\begin{tabular}{|c|l|c|c|c|l|}
\hline Number & \multicolumn{1}{|c|}{ Paragraph } & Mean & SD & Rank & Degree \\
\hline 1 & I can communicate and deal with others easily & 3.35 & 0.830 & 8 & High \\
\hline 2 & I deal with the pressures effectively & 3.76 & 0.88 & 12 & High \\
\hline 3 & distinguish between truth and opinion & 3.69 & 1.0 & 17 & High \\
\hline 4 & I have the skill to speak and listen carefully & 3.53 & 1.0 & 20 & Medium \\
\hline 5 & I have the skill to express what i feel & 3.78 & 1.10 & 9 & High \\
\hline 6 & I choose the most appropriate solution to the problems. & 3.90 & 0.98 & 6 & High \\
\hline 7 & I feel confident and proud & 3.78 & 1.0 & 9 & High \\
\hline 8 & link between study and application in real life & 3.72 & 0.96 & 16 & High \\
\hline 9 & I perform tasks with high level & 3.95 & 0.88 & 3 & High \\
\hline 10 & I can establish good relations with friends & 3.68 & 1.06 & 18 & High \\
\hline 11 & I adapt easily to the requirement of change & 3.73 & 0.99 & 15 & High \\
\hline 12 & I can discuss in a scientific manner & 3.67 & 1.10 & 19 & High \\
\hline 13 & I can identify my strengths & 3.78 & 0.92 & 9 & High \\
\hline 14 & I can perform tasks individually & 3.76 & 0.95 & 12 & High \\
\hline 15 & I have reading skill & 3.96 & 0.96 & 2 & High \\
\hline 16 & I have decision making skill & 3.86 & 1.02 & 7 & High \\
\hline 17 & I can deal positively with surroundings & 4.02 & 0.93 & 1 & High \\
\hline 18 & I have good communication skill & 3.75 & 0.96 & 14 & High \\
\hline 19 & I have very great leadership quality & 3.92 & 0.98 & 5 & High \\
\hline 20 & I can lead a team with perfect actions. & 3.93 & 0.95 & 4 & High \\
\hline
\end{tabular}

*Life skills as a whole $\quad 3.80 \quad 0.55 \quad--\quad$ High

Table 4. Descriptive Statistics of Reflective Thinking

\begin{tabular}{|c|l|c|c|c|l|}
\hline Number & \multicolumn{1}{|c|}{ Paragraph } & Mean & SD & Rank & Degree \\
\hline 1 & $\begin{array}{l}\text { I can figure out the main cause of the problem and analyze it } \\
\text { carefully, so that I can reach the solution. }\end{array}$ & 3.75 & 0.86 & 10 & High \\
\hline 2 & $\begin{array}{l}\text { I can visually identify aspects of the subject through images, } \\
\text { drawings and shapes. }\end{array}$ & 3.66 & 0.87 & 17 & High \\
\hline 3 & $\begin{array}{l}\text { I can develop logical steps to solve problems through mental } \\
\text { perceptions of the problem. }\end{array}$ & 3.75 & 1.01 & 10 & High \\
\hline 4 & $\begin{array}{l}\text { I provide an accurate explanation of the words, drawings and } \\
\text { questions. }\end{array}$ & 3.58 & 1.02 & 19 & High \\
\hline 5 & $\begin{array}{l}\text { I analyze and deepen thoughts. } \\
\text { Suggest logical alternatives to ideas. }\end{array}$ & 3.73 & 1.04 & 15 & High \\
\hline 7 & $\begin{array}{l}\text { I can make sound decisions depending on the nature of the } \\
\text { situation. }\end{array}$ & 3.76 & 0.98 & 9 & High \\
\hline 8 & $\begin{array}{l}\text { I can draw a particular result through the information and the } \\
\text { bytes contained in a particular position. }\end{array}$ & 3.74 & 0.98 & 13 & High \\
\hline 9 & $\begin{array}{l}\text { Make logical explanations of situations by linking causes and } \\
\text { consequences. }\end{array}$ & 3.79 & 0.87 & 7 & High \\
\hline 10 & $\begin{array}{l}\text { I can reach logical results and solutions to the problem posed } \\
\text { by available information }\end{array}$ & 3.57 & 1.06 & 20 & High \\
\hline
\end{tabular}




\begin{tabular}{|l|l|c|l|l|l|}
\hline 11 & I can discuss rationalized ideas & 3.70 & 1.02 & 16 & high \\
\hline 12 & I can link observations and conclusions & 3.63 & 1.10 & 18 & High \\
\hline 13 & give correct and logical justifications for things & 3.74 & 1.01 & 13 & High \\
\hline 14 & I can achieve a logical sequence of ideas & 3.79 & 0.95 & 7 & High \\
\hline 15 & I analyze various concepts logically. & 3.80 & 0.91 & 1 & High \\
\hline 16 & I can analyze and hope lesson. & 3.88 & 1.01 & 6 & High \\
\hline 17 & I can deduce the purpose of the lesson. & 3.75 & 0.90 & 3 & High \\
\hline 18 & I can provide convincing evidence to solve my problems. & 3.95 & 0.89 & 10 & High \\
\hline 19 & I can distinguish between the pros and cons of each subject. & 3.83 & 0.94 & 2 & High \\
\hline 20 & I can describe and connect and liken things & 3.89 & 0.94 & 5 & high \\
\hline
\end{tabular}

Table (4) shows that the mean for the field of "reflective thinking" ranged between 3.57-3.96, the highest of which is paragraph (15), which states "solving different concepts logically" with a mean (3.96) and a high degree, (19), which states that "I can distinguish between the pros and cons of each subject" with an average of 3.95 and a high score, and then paragraph 17, which states "I can deduce the objective of the lesson" with an average of 3.88 and high, Paragraph (10), which states that "I can reach logical results and solutions to the problem posed by available information on the nature of the problem and the specifics And then determine the procedural steps necessary to solve them "with an average of (3.57) and a medium degree, and the mathematical average of the field of" reflective thinking "as a whole (3.76) and high. This is due to the fact that the use of drama in education helps to develop the abilities of students and refine the skills of conclusion analysis and criticism by embodying different dramatic situations leading them to deep thinking and logical analysis of concepts, thus developing their perceptions of sensory, Tossing them. The results of this study agree with the results of the study, which showed that drama-based education makes education easier to understand and better by providing the opportunity to develop engineering context contexts, communicate and study in a collaborative learning environment. It also motivates attitudes by attracting students' attention to an exciting, stimulating and interesting learning environment.

Results related to the answer to the first question: What is an impact of the drama uses in education on the life skills for students in the tenth grade?

In order to answer this question, the Means and standard deviations of life skills were extracted corresponding to pre and post. The Paired sample t-test was also used to investigate the effect of the use of drama in education on the life skills of the tenth grade students.

Table 5. The results of Paired sample t-Test for the life skills scales (pre and post).

\begin{tabular}{|l|l|l|l|l|l|}
\hline Area & Measurement & Mean & St.Dex & t. Value & Sig. \\
\hline \multirow{2}{*}{ Life skills } & pre & 2.17 & 0.24 & \multirow{2}{*}{-26.580} & \multirow{2}{*}{0.00} \\
\cline { 2 - 4 } & post & 3.80 & 0.55 & & \\
\hline
\end{tabular}


Table (5) shows there are statistically significant differences at the level of significance $(\alpha=0.05)$ between pre and post parameters of life skills scales, where " $t$ " values reached (26.580) $(\alpha=0.000)$ where the post mean was 3.80, while the pre mean was 2.17. Because the fact that the use of drama in education helps to develop the life skills of students significantly, where they develop reading and numeracy skills, and the ability to identify the strengths and weaknesses they have, and enable them to link the study and the reality of life. This result was consistent with the results of the study, where there were statistically significant differences in the percentages and frequency of the three main axes: linguistic health, audio excellence, and clarity. For the post-test is attributed to the training program based on drama.

It also agreed with study that there were statistically significant differences between students in both groups in scholastic achievement due to the method of drama representation and for the benefit of the experimental group.

Results related to the second question: What is an impact of the drama uses in education on the reflective thinking for the tenth grade students?

In order to answer this question, the means and standard deviations of the reflective thinking were extracted corresponding to the pre and post-measurements. The Paired sample t-test was also used to reveal the effect of the use of drama in education on the reflective thinking of the tenth-grade students.

Table 6. The results of Paired Sample t. Test for the Reflective Thinking Scales (Pre and Post).

\begin{tabular}{|l|l|l|l|l|l|}
\hline area & Measurement & Mean & St.Dex & t. Value & Sig. \\
\hline $\begin{array}{l}\text { Reflective } \\
\text { Thinking }\end{array}$ & pre & 2.34 & 0.45 & -18.089 & 0.00 \\
\cline { 2 - 5 } & post & 3.76 & 0.59 & & \\
\hline
\end{tabular}

Table (6) shows that there are statistically significant differences at the level of significance $(0.00=\alpha)$ between the mean of the reflective thinking corresponding to pre and post measurements. The values of " $t$ " reached (18.089), Post mean was (3.76) while the mean of the pre-measurement was (2.34). This is because the use of educational drama helps students to develop their reflective thinking skills, increasing their ability to analyze different concepts logically, and also the ability to distinguish between the pros and cons of each subject, and increases their ability to deduce the goal of the lesson, And logical solutions to problems posed by available information on the nature of the problem.

\section{$7 \quad$ Recommendations}

Based on the results of the study, the researcher suggests the following recommendations:

- The teacher should focus on developing students' ability to differentiate between necessary information and non-essential information. 
- The teacher should focus on developing the students' ability to find solutions to the problems posed by the available information about the nature of the problem and its characteristics.

- There is a need to highlight the role of the teacher in developing a sense of selfconfidence and self-esteem among students.

- There is a need for the teacher to focus on developing communication between the students, which is a course that promotes the natural cooperation skills of the students, and stimulates their thinking.

- There is a need the teacher to focus on the need to discuss ideas with students in rational manner.

- There is a need for the teacher to focus on the development of the skills of students regarding linking observations and conclusions in a causal manner, to enhance their reflective thinking.

- The teacher should focus on developing student's communication skills and promote the art of communicating with others.

- There is a need to encourage students to perform the tasks entrusted to them with high efficiency, accuracy, and proficiency.

\section{References}

[1] Abdel Wahab, F. (2005). Effectiveness of the use of meta-knowledge strategies in the collection of physics and the development of reflective thinking and the trend towards its use by students in the second grade secondary Azhari, Journal of the College of Scientific Education, 8 (4), 159-2012.

[2] Adıgüzel, H. Ö., \& Timuçin, E. (2010). The effect of creative drama on student achievement in the instruction of some development and learning theories. Procedia-Social and Behavioral Sciences, 9, 1741-1746. https://doi.org/10.1016/j.sbspro.2010.12.393

[3] Afana, Ezzo and Al-Louh, Ahmed Hassan (2008). Teaching theater, Dar Al-Masirah, Amman, Jordan.

[4] Agha, Ihsan K. and Lulu (2009). Teaching Science in General Education, Master Thesis, Islamic University, Gaza, Palestine.

[5] Al Awadi, K. Abdul Rahman. (2008). A proposed training program in the development of life skills for sixth grade students, Master Thesis, King Saud University, College of Education, Saudi Arabia.

[6] Al-Assoud, A. (2006). Experience in Learning Through Drama, Roua Magazine, Issue (22), Al Qattan Center for Educational Research and Development, Ramallah, Palestine.

[7] Al-Badi, M. (2013). The Effect of Drama in Developing Life Skills in the Arabic Language among Fourth Grade Students in North Gaza Governorate, Master Thesis, Al-Azhar University, Gaza.

[8] Albalawi, B. (2014). Effectiveness of Teaching English Subject using Drama on the Development of Students' Creative Thinking, IOSR Journal of Research \& Method in Education (IOSR-JRME), 4(6), P 54-63. https://doi.org/10.9790/7388-04615463

[9] Al-Thaqafi, A. and others. (2013). Social Values and its Relation to Reflective Thinking among the Students of the Department of Special Education in the Taif University, Arab Journal for the Development of Excellence, No. (6). 
[10] Al Naji, A.S. (2010). What skills should secondary students learn?, Knowledge Magazine, Issue (170), Saudi Arabia.

[11] Asacus, P. (2005). Development of life skills among secondary school students in the framework of future curricula, National Center for Educational Research and Development, Cairo.

[12] Bamford, A. (2006). The wow factor: Global research compendium on the impact of the arts in education. Germany: Waxmann Verlag.

[13] Butcher, K., Pearce, G., \& Ross, D. (2017). Using educational drama to teach investments management: Evidence of cross-cultural relevance from Australia and China. The International Journal of Management Education, 15, 1, 67-83. https://doi.org/10.1016/j.ijme.2017.01.005

[14] Costa, N., Faccio, E., Belloni, E., \& Iudici, A. (2014). Drama Experience in Educational Interventions. Procedia - Social and Behavioral Sciences, 116, 4977-4982. https://doi.org/10.1016/j.sbspro.2014.01.1058

[15] Duatepe-Paksu, A., \& Ubuz, B. (2009). Effects of drama-based geometry instruction on student achievement, attitudes, and thinking levels. The Journal of Educational Research, 102(4), 272-286. https://doi.org/10.3200/JOER.102.4.272-286

[16] Guil, E., \& Gücüm, E. B. (2015). Creative Drama Applications as Complementary for Constructivist Approaches for Science Courses: Teacher and Student's Evaluations. Procedia Social and Behavioral Sciences, 174, 2043-2050. https://doi.org/10.10 16/j.sbspro.2015.01.875

[17] Şengün, Y., \& İskenderoğlua, T. (2010). A review of creative drama studies in math education: aim, data collection, data analyses, sample and conclusions of studies. Procedia Social and Behavioral Sciences, 9, 1214-1219. https://doi.org/10.10 16/j.sbspro.2010.12.309

[18] Şengün, Y., \& İskenderoğlua, T. (2010). A review of creative drama studies in math education: aim, data collection, data analyses, sample and conclusions of studies. Procedia Social and Behavioral Sciences, 9, 1214-1219. https://doi.org/10.101 6/j.sbspro.2010.12.309

[19] Hindi, M.R. (2002). Effectiveness of the use of cooperative learning strategy in teaching social studies on life skills development, achievement and the trend towards the material in the first grade students, Journal of Studies in Curriculum and Teaching Methods, No. 80.

[20] Ibrahim, M. (2005). Thinking from an educational perspective Definition - nature - skill development - patterns, world books, Cairo, Egypt.

[21] Ibrahim, N.R.M. (2011). Multiple Intelligence. 1, Amman, Dar Safa for Publishing and Distribution.

[22] Khasawneh, N. and Al-Akl, I. (2012). The Effectiveness of Drama in the Development of Oral Conversation Skills in Primary School Students, International Specialized Educational Journal, 1 (4), 182-206, Saudi Arabia.

[23] Mages, W. K. (2018). Does theatre-in-education promote early childhood development? The effect of drama on language, perspective-taking, and imagination. Early Childhood Research Quarterly. https://doi.org/10.1016/j.ecresq.2017.12.006

[24] Massoud, R.H.J. (2002). The effectiveness of the use of cooperative learning strategy in teaching social studies on life skills development, collection and the trend towards the material in the first grade pupils. Journal of Studies in Curriculum and Instruction, No. 80, Egypt.

[25] Moran, E. (2009). Understanding the human condition: the bet of future education. Journal of Educational Views, 122-128. 
[26] Özbek, G. (2014). Drama in education: key conceptual features. Sodobna Pedagogika, 65(1), 46.

[27] Ozdemir, S. M., \& Cakmak, A. (2008). The Effect of Drama Education on Prospective Teachers' Creativity. Online Submission, 1(1), 13-30.

[28] Pardun, J. (2004). Social issue drama and its impact on the social consciousness of preadolescent school children. Dissertation Abstracts International, A 65/04. P 1184.

[29] Qatami, N. (2004). Teaching thinking of the basic stage. 1, Dar Al Fikr Publishing and Distribution, Amman, Jordan.

[30] Jabbar, D. (2004). Different Thinking and Development of Creative Thinking Skills in Children, Journal of Education, Amman, Jordan.

[31] Owda, J.Y. (2010). The Effect of Using Dramatic Activities on the Achievement of Sixth Grade Students in Science and their Orientation towards them, Master Thesis, Birzeit, Palestine.

[32] Saad Al-Din, H. (2007). Life skills included in the 10th grade technology curriculum and the extent to which students have acquired it, unpublished message, Islamic University, Gaza.

[33] Şengün, Y., \& İskenderoğlua, T. (2010). A review of creative drama studies in math education: aim, data collection, data analyses, sample and conclusions of studies. Procedia Social and Behavioral Sciences, 9, 1214-1219. https://doi.org/10.10 16/j.sbspro.2010.12.309

[34] Suleiman, A. (2005). Learn Children Drama, Theater, Fine Arts, Music, Dar Al Safa, Amman, Jordan.

[35] Tashman, G. and Al-Khuraish, S, and the assistant, Mufidi and Muqtasat, Mohammed. (2012). The Impact of Using My Strategies: Multiple Intelligences and Conceptual Maps in the Development of Reflective Thinking in the Geography of the Arab World in the Students of the Class Teacher at Al Isra University in Jordan, Journal of the Islamic University for Educational and Psychological Studies, 20 (1), pp. 243-281, Amman, Jordan .

[36] Qararraa, A.O. (2009). Teaching Design Applied Vision, Book Chapter (Issue)1, Dar Al Shorouk Publishing \& Distribution, Amman, Jordan.

[37] Ulas, A. H. (2008). Effects of creative, educational drama activities on developing oral skills in primary school children. American Journal of Applied Sciences, 5(7), 876-880. https://doi.org/10.3844/ajassp.2008.876.880

\section{$9 \quad$ Author}

Hani Yousef Mahmood Al-Jarrah received his $\mathrm{PhD}$ and Master's in Curriculum and Teaching Methods in the Amman Arab University for Higher Studies in 2008 and 2004, respectively. In 2000, he obtained his Master's in Education Science in the Juba University, Higher Diploma in Education in the Jordanian University in 1991 and Bachelor's in Fine Arts in the Al Yarmouk University, 1985. He was the King Abdullah II Awardee for Excellence Government Performance and Transparency and Distinguished Leader Government Employee in 2009. His research interest includes ICDL, computer illiteracy eradication, drama in education, leadership, INTEL and quality management. He published School Theater Activities and its Techniques, Art Education Manuals Ethical Education, Introduction to Fine Arts, 'Academic attitudes in the light of multiple intelligences theory for students of Al-Ain University on modern teaching methods/AD (pending) and 'Moral intelligence and its relationship to 
self-esteem and motivation to accomplish (pending). He was the Deputy Dean of Education and Associate Professor in the Al-Ain University of Science in 2015 and 2012-2014, respectively. He served as Cultural Attaché in the Jordan Embassy in 2012 - 2014. He became part time Lecturer in 2008 - 2012, an expert in educational drama in 1990, the Director of Educational Activities in the Ministry of Education and Director of Cultural and Artistic Activities in 2010 - 2012 and 2005-2012, respectively. He was also a Section Head of Drama Activities in 1999-2005 and teacher in the Ministry of Education in 1985-1999.

Article submitted 2017-11-12. Resubmitted 2018-09-19. Final acceptance 2018-11-07. Final version published as submitted by the authors. 